\section{Strawberry Cultivar Evaluation under High-tunnel and Organic Management in North Carolina}

\author{
Sanjun $\mathrm{Gu}^{1,3}$, Wenjing Guan ${ }^{2}$, and John E. Beck ${ }^{1}$
}

ADDITIONAL INDEX WORDs. Fragaria $\times$ ananassa, day-neutral, June-bearing

Summary. High-tunnel strawberry (Fragaria $\times$ ananassa) production for extended seasons has a great economic potential for small farmers. However, information on cultivars that are suitable for high tunnels is rather limited. In this study conducted in the 2014-15 season, strawberry plugs of eight June-bearing cultivars (Florida Radiance, Benicia, Camarosa, Camino Real, Chandler, Strawberry Festival, Sweet Charlie, and Winterstar) and two day-neutral cultivars (San Andreas and Albion) were evaluated for yield performance, fruit quality, and vegetative growth in organically managed high tunnels at two locations in North Carolina. Significant cultivar differences in whole-season yield were observed at Greensboro, NC; but not at Goldsboro, NC. The cultivar Florida Radiance had the highest marketable and total yields, followed by Winterstar and Chandler at Greensboro, whereas Benicia, Winterstar, and Chandler were the top producing cultivars at Goldsboro. Harvest of day-neutral cultivars San Andreas and Albion started in November. For Junebearing cultivars, Florida Radiance began to produce harvestable berries in late December, followed by Winterstar in early January. Peak harvest occurred in April for all cultivars. At the end of the season, 'Albion' had smaller canopy size than other cultivars. It also developed the fewest number of branch crowns and least aboveground biomass. Total soluble solid (TSS) content in April was lower than that observed early and late in the season for all cultivars, although Strawberry Festival exhibited a relatively stable TSS throughout the season. 'Benicia' produced the largest strawberries in the early season, but its fruit weight was remarkably reduced as the season progressed. Severe frost events occurred on 18 and $20 \mathrm{Feb}$. that caused an average of $61.5 \%$ and $32.2 \%$ open blossom damage at Greensboro and Goldsboro, respectively. The recommended cultivars based on this 1-year study are Florida Radiance, Benicia, and Camino Real for June-bearing cultivars, and Albion and San Andreas for day-neutral cultivars.

S trawberry is an important component of a healthy diet (Giampieri et al., 2012). Consumption of fresh strawberries increased from $2 \mathrm{lb} /$ person in 1980 to $7.9 \mathrm{lb} /$ person in 2013 [U.S. Department of Agriculture (USDA), 2014]. Corresponding with increasing demand, production of fresh strawberries reached 24.2 million cwt, with a market value of $\$ 2.2$ billion in 2012 . North Carolina ranked fourth in strawberry production in the United States in 2013 (USDA, 2013). Distinguishing itself from other states, strawberry production in North Carolina is almost exclusively for local fresh markets, including pick-your-own operations, roadside stands, and farmers' markets, with a market value of $\$ 29.4$

${ }^{1}$ North Carolina A\&T State University, Cooperative Extension, 1601 E. Market Street, Greensboro, NC 27411

${ }^{2}$ Purdue University, West Lafayette, IN 47907

${ }^{3}$ Corresponding author. E-mail: sgu@ncat.edu.

doi: 10.21273/HORTTECH03559-16 million in 2012 (McWhirt et al., 2015; USDA, 2013).

Commercial strawberry cultivars have undergone tremendous changes in the past few decades. Ninety-eight strawberry cultivars were introduced to the United States from 1980 to 2000 (Faedi, et al., 2002), and more than 15 cultivars were released thereafter (Clark and Finn, 2010; Finn and Clark, 2012; Gasic and Preece, 2014). Changing production systems, reductions in chemical control options, and increasing desires for off-season and highquality strawberries drove strawberry breeding efforts in developing new cultivars to serve these diverse needs (Faedi et al., 2002; Hokanson and Finn, 2000).

According to photoperiodic flowering responses, strawberry cultivars are classified into three types: Junebearing, everbearing, and day-neutral. June-bearing or short-day cultivars require photoperiods less than $14 \mathrm{~h}$ to initiate flowering. They generally have one flush of harvest that peaks in the spring. Everbearing cultivars initiate flowering under long days, and often result in a fall harvest, or in some cases, two crops in 1 year. The third distinctive type, day-neutral cultivars are insensitive to daylength with regard to flower initiation and have multiple harvests throughout the season (Rowley et al., 2010a; Stewart and Folta, 2010).

Open-field annual hill production is the primary strawberry production system in North Carolina. With this system, strawberries are planted in the fall on raised beds covered with black plastic mulch. Harvests take place around May and last for 4 to 6 weeks (Fernandez et al., 2001; Poling, 1993). Two or three different strawberry cultivars are often grown to extend the harvest season. A typical mix includes June-bearing cultivars Chandler, Camarosa, and Sweet Charlie (Poling et al., 2005), which were released more than 20 years ago.

Apart from the short peak season, strawberries are shipped long distances to North Carolina. Driven by the growing interest of local and regional food, there is a strong demand for locally produced off-season strawberries. To extend the strawberry production season in North Carolina,

\begin{tabular}{llll}
\hline $\begin{array}{l}\text { Units } \\
\text { To convert U.S. to SI, } \\
\text { multiply by }\end{array}$ & U.S. unit & SI unit & $\begin{array}{l}\text { To convert SI to U.S., } \\
\text { multiply by }\end{array}$ \\
\hline 0.4047 & $\mathrm{acre}(\mathrm{s})$ & $\mathrm{ha}$ & 2.4711 \\
45.3592 & $\mathrm{cwt}$ & $\mathrm{kg}$ & 0.0220 \\
0.3048 & $\mathrm{ft}$ & $\mathrm{m}$ & 3.2808 \\
0.0929 & $\mathrm{ft}^{2}$ & $\mathrm{~m}^{2}$ & 10.7639 \\
2.54 & $\mathrm{inch}(\mathrm{es})$ & $\mathrm{cm}$ & 0.3937 \\
0.4536 & $\mathrm{lb}$ & $\mathrm{kg}$ & 2.2046 \\
1.1209 & $\mathrm{lb} / \mathrm{acre}$ & $\mathrm{kg} \cdot \mathrm{ha}^{-1}$ & 0.8922 \\
0.0254 & $\mathrm{mil}$ & $\mathrm{mm}$ & 39.3701 \\
1 & $\mathrm{mmho} / \mathrm{cm}$ & $\mathrm{mS} \cdot \mathrm{cm}^{-1}$ & 1 \\
28.3495 & $\mathrm{oz}$ & $\mathrm{g}$ & 0.0353 \\
33.9057 & $\mathrm{oz} / \mathrm{yard}{ }^{2}$ & $\mathrm{~g} \cdot \mathrm{m}^{-2}$ & 0.0295 \\
$\left({ }^{\circ} \mathrm{F}-32\right) \div 1.8$ & ${ }^{\circ} \mathrm{F}$ & ${ }^{\circ} \mathrm{C}$ & $\left({ }^{\circ} \mathrm{C} \times 1.8\right)+32$
\end{tabular}


approaches such as planting day-neutral strawberries, applying floating rowcovers, and using overhead sprinkler irrigation have been explored (Ballington et al., 2008; Fernandez and Ballington, 2002; Poling, 2011). However, successful off-season production has been limited due to variable environmental conditions and pest damage.

While the majority of strawberries are produced conventionally, demand for organic strawberries is increasing. Consumers perceive organic fruit to be more environmental friendly, safer, tastier, and more nutritious than conventional ones (Zhao et al., 2006), and will pay premium prices for organic strawberries. In addition, organic strawberries are the most widely distributed organic produce item found year-round in mainstream retail stores (Carolina Farm Stewardship Association, 2013). According to Carolina Farm Stewardship Association (2013), a weekly gap of $11,410 \mathrm{lb}$ existed between regional demand for organic strawberries and what North Carolina growers and California shippers are currently supplying.

High tunnels are one of the most important tools for small farmers to practice season extension. By increasing temperatures in winter and early spring, high tunnels advanced fruit production of June-bearing strawberries by 4 and 5 weeks in Utah and Kansas, respectively (Kadir et al., 2006; Rowley et al., 2010b). If managed properly, high tunnels also enhance organic production, as the structures limit access and interference of pests and weeds, and reduce the need for chemical control (Huff, 2015). Cultivar selection is one of the key factors to ensure success in hightunnel production. Promising cultivars should be able to adapt to unique microclimatic conditions in high tunnels (i.e., high humidity, low light, and extreme differences between day and night temperatures). In addition, they should have the potential for fruiting in early and/or late seasons.

Considering the large number of newly released strawberry cultivars and the demand for off-season locally produced organic strawberries, objectives of this study were to evaluate performance of strawberry cultivars under organic and high-tunnel production systems, with the goal of developing guidelines for organic high-tunnel strawberry production in North Carolina.

\section{Materials and methods}

Planting and High-tunnel MANAGEMENT. Experiments were conducted at two sites: University Farm of North Carolina Agricultural \& Technical State University, Greensboro, NC (USDA Hardiness Zone 7b) and Small Farm Unit of the Center for Environmental Farming Systems, Goldsboro, NC (USDA Hardiness Zone 8a). Soil types were Enon fine sandy loam and Wickham loamy sand at Greensboro and Goldsboro sites, respectively. High tunnels [Greensboro (MCS Tuff high tunnel; Morgan County Seeds, Barnett, MO), Goldsboro (30 Budget Plus; Atlas Greenhouse Systems, Alapaha, GA)] at both sites were constructed in Aug. 2014 with north-south orientations. High tunnels were $30 \mathrm{ft}$ wide and $96 \mathrm{ft}$ long, with 8 - and 6 -ft side walls at Greensboro and Goldsboro sites, respectively. Both structures were covered with a single layer of 6-mil greenhouse-grade polyethylene film (FarmTek, Dyersville, IA). At Greensboro, the land was in the second year of organic transition, the previous crops were organically managed strawberries (up to June 2014, then no crops were planted before construction). In Goldsboro, the land had been managed organically for more than 10 years; the previous crops were organically managed sweet corn (Zea mays) before construction.

Ten strawberry cultivars were evaluated in the study: San Andreas and Albion are day-neutral cultivars; Florida Radiance, Benicia, Camarosa, Camino Real, Chandler, Strawberry Festival, Sweet Charlie, and Winterstar are June-bearing cultivars. Plugs of 'San Andreas', 'Florida Radiance', 'Benicia', 'Camino Real', and 'Winterstar' were conventionally raised (Norton Creek Farms, Cashiers, NC), while plugs of the other cultivars were organically raised (Cottle Strawberry Nursery, Faison, NC).

Strawberry plugs were transplanted on 30 Sept. 2014 on raised beds. Six beds, measured at 30 inches wide and 4 inches high with $4-\mathrm{ft}$ center-to-center bed spacing, were made inside each high tunnel. The beds were covered with 48-inch, 1.25-mil embossed black plastic mulch (Berry
Hill Irrigation, Buffalo Junction, VA). One 8-mil drip tape with 8-inch emitter spacing was placed in the middle of each bed ( $\mathrm{T}$-Tape Systems; Rivulis Irrigation, San Diego, CA). A completely randomized experimental design with three replications of each cultivar was used at both sites. Each experimental plot contained 18 strawberry plants that were planted in two rows and staggered 14 inches apart.

High tunnels were closed when night temperatures were below $55^{\circ} \mathrm{F}$ and opened during the day when temperatures reached $70-75{ }^{\circ} \mathrm{F}$. Double layers of $1.5 \mathrm{oz} / \mathrm{yard}^{2}$ rowcover (GroGuard; Atmore Industries, Atmore, AL) were laid directly on the plants at night for frost protection when outside temperatures were predicted to drop below $32{ }^{\circ} \mathrm{F}$.

FERTILITY A N D PES T MANAGEMENT. Both high tunnels were fertilized preplant with feathermeal (12N-0.5P-0K; Nutrimax, Greensboro, $\mathrm{NC}$ ) at $60 \mathrm{lb} /$ acre nitrogen $(\mathrm{N})$, sulfate of potash $(0 \mathrm{~N}-0 \mathrm{P}-42 \mathrm{~K}$; Compass Minerals, Overland Park, KS) at 83 $\mathrm{lb} /$ acre potassium $(\mathrm{K})$, soluble borate micronutrient (Beau-Ron ${ }^{\circledR} \mathrm{D}$; Drexel Chemical Co., Memphis, TN) at 0.98 $\mathrm{lb} /$ acre boron (B), and 10,000 lb/acre organic compost (Brooks Contractor, Goldston, NC). The organic compost had average properties of $6.9 \mathrm{pH}, 2.91$ $\mathrm{mS} \cdot \mathrm{cm}^{-1}$ electric conductivity, and a carbon to nitrogen ratio of 10.9:1. Estimated available nutrients for the crop are $0.6 \% \mathrm{~N}, 0.03 \%$ phosphorus $(\mathrm{P})$, $0.2 \% \mathrm{~K}, 10.3 \%$ calcium (Ca), $0.1 \%$ magnesium $(\mathrm{Mg})$, and $0.1 \%$ sulfur $(\mathrm{S})$. Plants were fertigated from March to May with fish emulsion $(2 \mathrm{~N}-0.9 \mathrm{P}-0 \mathrm{~K}$; SF Organics, Thomson, IL) at a weekly rate of $0.4 \mathrm{lb} /$ acre $\mathrm{N}$.

Organic Materials Review Institute listed pesticides potassium salts of fatty acids (M-Pede; Dow AgroSciences, Indianapolis, IN), Isaria fumosorosa Apopka Strain 97 (PFR97; Certis US, Columbia, MD), and Bacillus thuringiensis sp. kurstaki (DiPel; Valent BioSciences Corp., Libertyville, IL) were applied in a rotational scheme at rates based on product labels to control two-spotted spider mites (Tetranychus urticae) and aphids [green peach aphid (Myzus persicae), melon aphid (Aphids gossypii), and strawberry aphid (Chaetosiphon fragaefolii)] at both sites. In addition, predatory mites [Phytoseiulus persimilis 
(Spidex; Koppert Biological Systems, Howell, MI) ] at a rate of 1.4 adults/ $\mathrm{ft}^{2}$ were introduced on $23 \mathrm{Jan}$. and 30 Jan. 2015 at Greensboro to control two-spotted spider mites. Landscape fabric was laid in row middles to control weeds at Greensboro, whereas hand weeding was conducted at Goldsboro.

Data collection. Ripe strawberry fruit were harvested from 6 Nov. 2014 to 28 May 2015 and from 7 Nov. 2014 to 4 May 2015 at Greensboro and Goldsboro, respectively. Harvests were conducted once per week from November to February and twice per week in March, April, and May. Marketable and cull fruit (misshaped, damaged by diseases or insects, cold injured, or sunburned) were counted and weighed separately at each harvest. Following frost events from 18 to 20 Feb., percentages of damaged open blossoms were recorded on six randomly selected plants in each plot on 23 Feb. 2015. Plant canopy diameters were measured in early December, February, March, April, and May on six randomly selected plants in each plot. Border plants were avoided. Throughout the production season, runners were counted and removed on a weekly basis. At Greensboro, TSS contents of three typical marketable strawberry fruit per cultivar per replication were measured at six harvests (late February, early and late March and April, and early May) as described previously (SalaméDonoso et al., 2010). A handheld refractometer (Spectrum Technologies, Aurora, IL) was used for the measurements. Fruit TSS was measured once at the Goldsboro site during peak harvest in the middle of April. About 18 of the youngest fully expanded strawberry leaves and petioles were sampled from each experiment plot on 30 Apr. 2015 at the Greensboro site. Plant samples were sent to the North Carolina Department of Agriculture \& Consumer Services (Raleigh) for nutrient analysis. Data loggers (WatchDog 1650; Spectrum Technologies) were set at the height of plant canopies inside and outside of high tunnels to automatically record air temperatures at a 30-min interval throughout the season.

Statistical analyses. Analysis of variance was performed using the
Proc Mixed procedure of SAS (version 9.2C for Windows; SAS Institute, Cary, NC). Tukey's honest significant difference test $(\alpha=0.05)$ was conducted for multiple comparisons of different measurements among strawberry cultivars.

\section{Results and discussion}

YIELD. Cultivar effects on wholeseason strawberry yields differed between the two locations. Significant differences among cultivars were observed at Greensboro, but not Goldsboro (Table 1). 'Florida Radiance' had the highest total yield $(657 \mathrm{~g} /$ plant), followed by 'Winterstar' (total yield $585 \mathrm{~g} /$ plant) and 'Chandler' (total yield $569 \mathrm{~g} /$ plant) at Greensboro. 'Winterstar' and 'Chandler' also ranked second and third among the evaluated strawberry cultivars at Goldsboro in terms of the total yields, whereas Benicia was the top producer at this site with a total yield of $800 \mathrm{~g} /$ plant. Day-neutral cultivar Albion and June-bearing cultivar Sweet Charlie had the lowest yields at both locations; their total yields were 342 and $396 \mathrm{~g} /$ plant at Greensboro, and 440 and $332 \mathrm{~g} /$ plant at Goldsboro, respectively (Table 1$)$. Comparing yield performances between the two day-neutral cultivars, Albion had lower total and marketable yields than San Andreas, although the difference was not significant. These results are similar to those reported by Ruan et al. (2011); however, higher yields of 'Albion' in contrast to 'San Andreas' were noticed in Washington State (Hoashi-Erhardt et al., 2012).

Although 'Winterstar' exhibited the second highest total yield, its marketable yield ranked fourth, after 'Benicia', 'Chandler', and 'Camino Real' at both locations. When averaging among cultivars, marketable yield accounted for $75 \%$ and $66 \%$ of total yields at Greensboro and Goldsboro sites, respectively (Table 1 ).

Harvest of day-neutral cultivars started earlier than that of June-bearing cultivars at both locations. The first harvest was from 'Albion' on 6 Nov. (Greensboro) and 7 Nov. (Goldsboro), and 14-17 d later for 'San Andreas'. Among the June-bearing cultivars, Florida Radiance matured the earliest, with the first harvest occurring 87 and 79 d after transplanting at Greensboro and Goldsboro, respectively. This was about 2 weeks earlier than 'Winterstar' and a month earlier than other June-bearing cultivars (Table 2).

Peak harvest occurred in April for all strawberry cultivars evaluated in the study (Table 1). At Goldsboro, marketable yield in April accounted for more than $70 \%$ of entire season's harvest for June-bearing cultivars and $53 \%$ and $63 \%$ for day-neutral cultivars San Andreas and Albion, respectively. At Greensboro, the number ranged from 38\% for 'Strawberry Festival' to $71 \%$ for 'Benicia' (Table 1 ). Results of the study confirmed previous observations that high tunnels advanced strawberry harvests by 4 to 5 weeks (Kadir et al., 2006; Rowley et al., 2010b) considering peak harvests normally occur in May for open-field strawberries in North Carolina (Poling et al., 2005). In March, 'Winterstar' had 73 and $65 \mathrm{~g} /$ plant total yield at Greensboro and Goldsboro, respectively, the highest among other cultivars in this month. However, marketable yields were only 34 and $36 \mathrm{~g} /$ plant at Greensboro and Goldsboro, respectively. Deformed fruit developed from frost damaged flowers was the primary reason for low market yield from Winterstar, as well as other cultivars in March.

Released in 2009 by the Institute of Food and Agricultural Sciences, University of Florida, 'Florida Radiance' has become one of the major strawberry cultivars in Florida and some other early spring production regions worldwide (Chandler et al., 2009; Ohlemeier, 2011; Whitaker et al., 2012). Although 'Florida Radiance' was categorized as a short-day cultivar, it develops more flowers under long-day conditions and requires less chilling for flower initiation than typical short-day cultivars (Whitaker et al., 2013). Because of this unique characteristic, 'Florida Radiance' is recommended for protected culture systems (Whitaker et al., 2013). Using 'Florida Radiance' as one parent, 'Winterstar' was also developed by University of Florida, and released in 2011 (Whitaker et al., 2012). 'Winterstar' shares many desirable characteristics with 'Florida Radiance'. In the present study, 'Florida Radiance' was superior in early yield compared with 'Winterstar'; however, 'Winterstar' had more consistent yield than 'Florida Radiance'. 'Benicia' is a newly released cultivar 


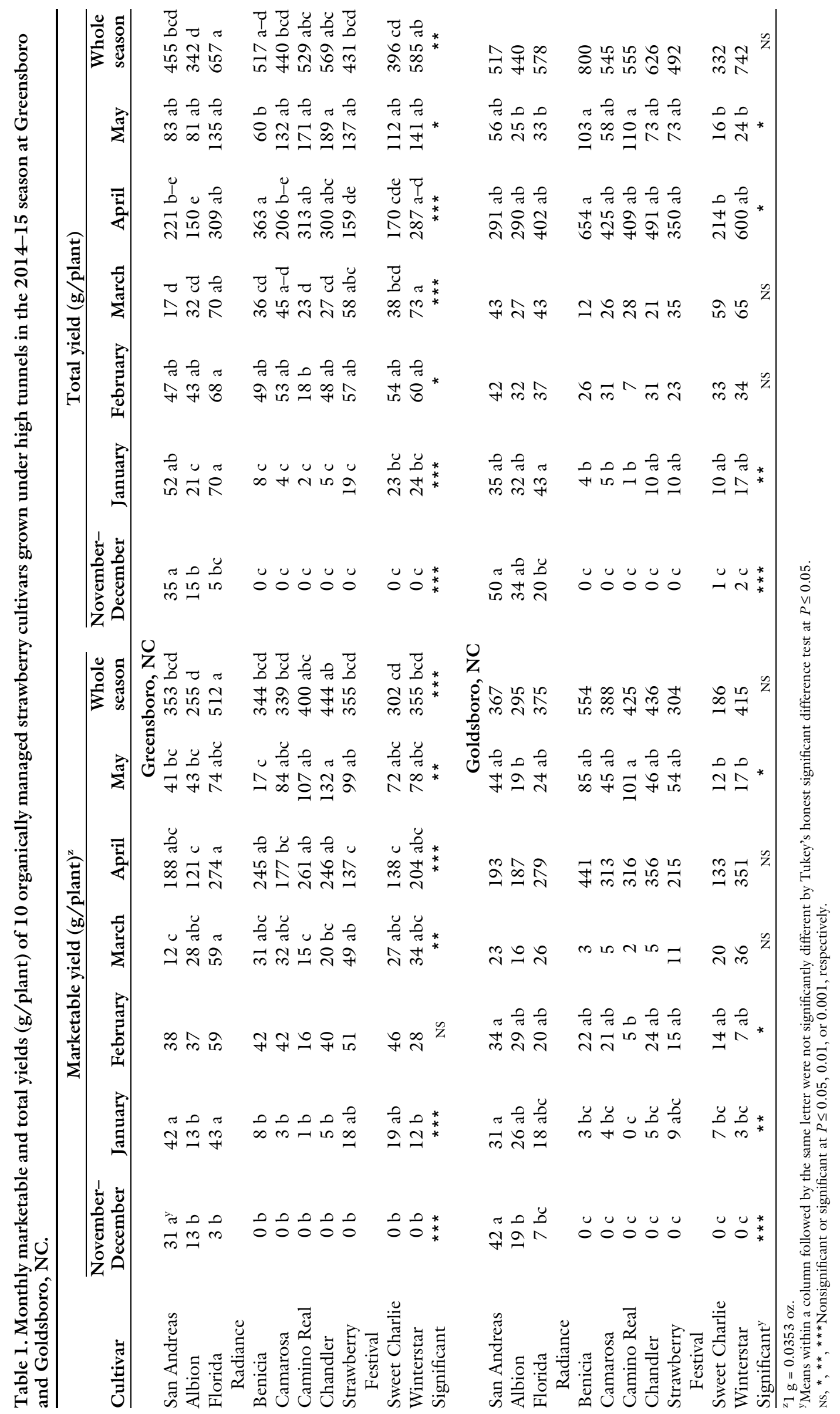


Table 2. First harvest dates and time after transplanting of 10 organically managed strawberry cultivars grown under high tunnels in the 2014-15 season at Greensboro and Goldsboro, NC.

\begin{tabular}{|c|c|c|c|c|}
\hline \multirow[b]{2}{*}{ Cultivar } & \multicolumn{2}{|c|}{ Greensboro, NC } & \multicolumn{2}{|c|}{ Goldsboro, NC } \\
\hline & First harvest date & Time after transplanting $(\mathrm{d})$ & First harvest date & Time after transplanting $(\mathrm{d})$ \\
\hline San Andreas & 20 Nov. & 51 & 24 Nov. & 55 \\
\hline Albion & 6 Nov. & 37 & 7 Nov. & 38 \\
\hline Florida Radiance & 26 Dec. & 87 & $18 \mathrm{Dec}$. & 79 \\
\hline Benicia & 22 Jan. & 114 & 22 Jan. & 114 \\
\hline Camarosa & 22 Jan. & 114 & 12 Jan. & 114 \\
\hline Strawberry Festival & 22 Jan. & 114 & 22 Jan. & 114 \\
\hline Sweet Charlie & 15 Jan. & 107 & 19 Jan. & 111 \\
\hline Winterstar & 1 Jan. & 93 & 5 Jan. & 97 \\
\hline
\end{tabular}

Table 3. Canopy diameters of 10 organically managed strawberry cultivars grown under high tunnels in the 2014-15 season at Greensboro NC.

\begin{tabular}{llcccc}
\hline & \multicolumn{5}{c}{ Canopy diam $(\mathbf{c m})^{\mathrm{z}}$} \\
\cline { 2 - 6 } Cultivar & December & February & March & April & May \\
\hline San Andreas & $22.7 \mathrm{abc}^{\mathrm{y}}$ & $19.1 \mathrm{bc}$ & $22.0 \mathrm{abc}$ & $27.4 \mathrm{bc}$ & $30.7 \mathrm{ab}$ \\
Albion & $19.3 \mathrm{bc}$ & $17.5 \mathrm{c}$ & $17.9 \mathrm{~d}$ & $22.0 \mathrm{c}$ & $24.1 \mathrm{~b}$ \\
Florida Radiance & $23.6 \mathrm{ab}$ & $22.9 \mathrm{ab}$ & $24.3 \mathrm{a}$ & $31.0 \mathrm{ab}$ & $37.5 \mathrm{a}$ \\
Benicia & $24.8 \mathrm{a}$ & $24.2 \mathrm{a}$ & $23.0 \mathrm{ab}$ & $25.2 \mathrm{bc}$ & $\mathrm{NA}^{\mathrm{x}}$ \\
Camarosa & $18.3 \mathrm{c}$ & $18.1 \mathrm{c}$ & $20.1 \mathrm{bcd}$ & $26.3 \mathrm{bc}$ & $30.0 \mathrm{ab}$ \\
Camino Real & $22.9 \mathrm{abc}$ & $23.2 \mathrm{ab}$ & $23.1 \mathrm{ab}$ & $28.7 \mathrm{~b}$ & $31.2 \mathrm{ab}$ \\
Chandler & $24.2 \mathrm{ab}$ & $23.1 \mathrm{ab}$ & $23.4 \mathrm{ab}$ & $34.6 \mathrm{a}$ & $37.9 \mathrm{a}$ \\
Strawberry Festival & $20.7 \mathrm{abc}$ & $19.6 \mathrm{bc}$ & $20.7 \mathrm{a}-\mathrm{d}$ & $28.0 \mathrm{~b}$ & $33.6 \mathrm{a}$ \\
Sweet Charlie & $19.4 \mathrm{bc}$ & $19.1 \mathrm{bc}$ & $19.3 \mathrm{~cd}$ & $27.3 \mathrm{bc}$ & $31.0 \mathrm{ab}$ \\
Winterstar & $21.5 \mathrm{abc}$ & $22.7 \mathrm{ab}$ & $21.9 \mathrm{abc}$ & $29.7 \mathrm{ab}$ & $36.3 \mathrm{a}$ \\
Significant & $* *$ & $* * *$ & $* * *$ & $* * *$ & $* *$ \\
\hline
\end{tabular}

${ }^{\mathrm{z}} 1 \mathrm{~cm}=0.3937$ inch.

${ }^{y}$ Means within a column followed by the same letter were not significantly different by Tukey's honest significant difference test at $P \leq 0.05$.

${ }^{\mathrm{x}} \mathrm{NA}=$ not available.

${ }^{* *},{ }^{* *}$ Significant at $P \leq 0.01$ and 0.001 , respectively

Table 4. Number of branch crowns and fresh weights of leaves and stems of 10 organically managed strawberry cultivars grown under high tunnels in 2014-15 season at Greensboro and Goldsboro, NC.

\begin{tabular}{lccccc}
\hline & \multicolumn{2}{c}{ Greensboro, NC } & & \multicolumn{2}{c}{ Goldsboro, NC } \\
\cline { 2 - 3 } \cline { 6 - 6 } Cultivar & $\begin{array}{c}\text { Branch } \\
\text { crowns (no.) }\end{array}$ & Fresh wt $(\mathbf{g})^{\mathrm{z}}$ & & $\begin{array}{c}\text { Branch } \\
\text { crowns (no.) }\end{array}$ & Fresh wt (g) \\
\hline San Andreas & $3.0 \mathrm{bcd}^{\mathrm{y}}$ & $115.9 \mathrm{c}$ & & $3.1 \mathrm{ab}$ & 281.7 \\
Albion & $2.2 \mathrm{~d}$ & $105.1 \mathrm{c}$ & & $2.9 \mathrm{~b}$ & 239.3 \\
Florida Radiance & $4.1 \mathrm{abc}$ & $209.1 \mathrm{ab}$ & & $3.4 \mathrm{ab}$ & 284.4 \\
Benicia & $2.5 \mathrm{bcd}$ & $91.7 \mathrm{c}$ & & $3.9 \mathrm{ab}$ & 411.7 \\
Camarosa & $2.3 \mathrm{~cd}$ & $132.2 \mathrm{c}$ & & $3.6 \mathrm{ab}$ & 440.5 \\
Camino Real & $3.3 \mathrm{bcd}$ & $132.8 \mathrm{bc}$ & & $4.2 \mathrm{ab}$ & 419.7 \\
Chandler & $4.6 \mathrm{ab}$ & $160.6 \mathrm{bc}$ & & $5.2 \mathrm{a}$ & 405.0 \\
Strawberry Festival & $3.2 \mathrm{bcd}$ & $157.6 \mathrm{bc}$ & & $3.3 \mathrm{ab}$ & 361.7 \\
Sweet Charlie & $2.7 \mathrm{bcd}$ & $126.4 \mathrm{c}$ & & $2.8 \mathrm{~b}$ & 246.7 \\
Winterstar & $5.3 \mathrm{a}$ & $240.6 \mathrm{a}$ & & $4.7 \mathrm{ab}$ & 374.4 \\
Significant & $* * *$ & $* * *$ & & $*$ & $\mathrm{NS}$ \\
\hline
\end{tabular}

${ }^{\mathrm{z}} 1 \mathrm{~g}=0.0353 \mathrm{oz}$.

${ }^{\mathrm{y}}$ Means within a column followed by the same letter were not significantly different by Tukey's honest significant difference test at $P \leq 0.05$

NS, ${ }^{*}, * *$ Nonsignificant or significant at $P \leq 0.05$ or 0.001 , respectively

by University of California, which is marketed for its high yield and large fruit (Gasic and Preece, 2014). Planting area of the cultivar has increased from 62 to 1165 acres within 2 years in the Oxnard district of California (Burfield, 2013). Currently, there is very little information regarding growing 'Benicia' under other production systems.

Vegetative growth. Canopy diameters of strawberry plants slightly declined from December to February and increased from March to May at Greensboro (Table 3). 'Albion' had the smallest canopy size in most months except in December at Greensboro. Throughout the season, 'Albion' and 'San Andreas' increased canopy sizes by 4.8 and $8 \mathrm{~cm}$, respectively, while more than $10 \mathrm{~cm}$ growth was observed on most Junebearing cultivars. 'Chandler', 'Florida Radiance', and 'Winterstar' had canopy diameters of over $36 \mathrm{~cm}$ in May. They also developed the most branch crowns and had the highest values on fresh weights of leaves and stems at the end of the season (Table 4). Similar trends of the growth of plant canopies were observed at Goldsboro (data not shown), but 'Camarosa', 'Benicia', 'Camino Real', and 'Chandler' exhibited higher values on fresh weights of leaves and crowns at the end of the season (Table 4).

Small canopy sizes of day-neutral cultivars suggest plant density can be increased to maximize yield in limited spaces under high tunnels. By comparing yields of 'Albion' grown at four plant spacings, Portz et al. (2011) noticed that there was no significant difference in strawberry yields between 10- and 12-inch spacing (spacing was measured within rows, between plants, and between rows). With canopy diameter of $24.1 \mathrm{~cm}$ at Greensboro, plant spacing of 'Albion' could be reduced from the present 14-inch to 10- or 12-inch spacing without sacrificing yield.

Developing three to four branch crowns is important to achieving 
adequate yield in the annual hill plasticulture system (Poling et al., 2005 ). A range of 2.2 to 5.3 branch crowns were formed at the end of the season in the present study. 'Albion' and 'Sweet Charlie' developed fewer than three branch crowns, and 'Chandler' and 'Winterstar' had more than four branch crowns at both locations (Table 4 ). Few runners were developed before April. This was particularly true for strawberries at Greensboro. At Goldsboro, 'Camino Real' had relatively more runners in fall, whereas 'Strawberry Festival' had more runners in spring (data not shown). Strawberry plants at Goldsboro generally developed more branch crowns and had higher fresh weight values of leaves and stems compared with plants at Goldsboro. This is mainly because Goldsboro has warmer climate than Greensboro.

Frost DAmage. Severe frost events occurred from 18 to 20 Feb. at both locations (Fig. 1). The night temperatures under rowcovers in the high tunnels averaged 18.8 and $16.7^{\circ} \mathrm{F}$ higher than temperatures outside the high tunnels at Greensboro and Goldsboro, respectively. The lowest temperature recorded outside during those $3 \mathrm{~d}$ was $6.5^{\circ} \mathrm{F}$ at Greensboro, whereas the temperature inside the high tunnel was $29.6{ }^{\circ} \mathrm{F}$ during that same time. Strawberry plants may be permanently damaged when the temperature is lower than $22^{\circ} \mathrm{F}$ (Poling et al., 2005). Therefore, severe cold damage was prevented for plants under rowcovers in high tunnels during these freeze events.

Under protected culture, periods with temperatures lower than $32{ }^{\circ} \mathrm{F}$ lasted for 4.5 and $5 \mathrm{~h}$ on 19 and $20 \mathrm{Feb}$. at Greensboro and lasted for $4 \mathrm{~h}$ on $20 \mathrm{Feb}$. at Goldsboro. The freezing temperatures resulted in an average of $61.5 \%$ and $32.2 \%$ open blossom damage at Greensboro and Goldsboro, respectively (Table 5). Many of the damaged flowers were primary or secondary flowers that develop large and early maturing fruit and have been reported to contribute the most to marketable yield (Pollard et al., 1989). Using plastic-covered low tunnels inside high tunnels or adding supplemental heating has achieved success in frost protection and early season strawberry production in Utah (Maughan et al., 2015). These practices warrant future investigation to further early season production of strawberries in North Carolina.

Fruit Characteristics. Fruit quality of the same cultivar differed remarkably during the season. Of all the evaluated strawberry cultivars, TSS declined as the season progressed to the peak harvest, and reached the lowest value in early April (Table 6). However, TSS recovered toward the end of the season. When averaging among cultivars, TSS was $10.1 \%$ in February, $5.7 \%$ in early April, and $10.1 \%$ in early May. These data support previous observations that TSS of strawberries is correlated with crop load and not determined by temperature during the production season (Agüero et al., 2015).

In early April, TSS content of all evaluated strawberry cultivars, except Sweet Charlie, was lower than 7\%, the minimum requirement for U.S. no. 1 grade strawberry fruit (Mitcham, 2014). In May, 'Sweet Charlie' had the highest TSS, although it was relatively low in late February. Similar to 'Sweet Charlie', 'Albion' also exhibited high TSS late in the season but relatively low TSS early in the season. Among all evaluated strawberry cultivars, TSS of Strawberry Festival was above cultivar average in all harvest periods (11.4\% in February, $6.8 \%$ in early April, and $10.8 \%$ in early May).

Continuous decreasing fruit weight was observed for all the evaluated strawberry cultivars at both locations (Table 7), which supports the statement that fruit weight can be

Table 5. Percentages of frost damaged open blossoms of 10 organically managed strawberry cultivars grown under high tunnels in 2014-15 season at Greensboro and Goldsboro, NC. ${ }^{\mathrm{z}}$

\begin{tabular}{lcc}
\hline & \multicolumn{2}{c}{ Open blossom damage (\%) } \\
\cline { 2 - 3 } Cultivar & Greensboro, NC & Goldsboro, NC \\
\hline San Andreas & 65.8 & 47.1 \\
Albion & 67.6 & 30.0 \\
Florida Radiance & 59.2 & 22.0 \\
Benicia & 69.6 & 43.4 \\
Camarosa & 80.1 & 27.5 \\
Camino Real & 49.6 & 38.8 \\
Chandler & 70.6 & 34.8 \\
Strawberry Festival & 64.7 & 26.4 \\
Sweet Charlie & 53.2 & 35.0 \\
Winterstar & 34.7 & 17.2 \\
Significant & $\mathrm{NS}$ & $\mathrm{NS}$
\end{tabular}

${ }^{\mathrm{z}}$ Frost events occurred on 18 and 20 Feb. 2015; data were collected on 23 Feb. 2015.

NS $=$ Nonsignificant at $P \leq 0.05$. a temperature-determined characteristic (Agüero et al., 2015). When temperatures rise, fruit become smaller (Chen, 2013). Fruit harvested late in the season are more likely developed from secondary or tertiary flowers in a flower cluster that may lead to smaller fruit size. With eight out of 10 cultivars, fruit weights in May were less than half of fruit weight in January. Of the evaluated strawberry cultivars, average fruit weight of Benicia was the greatest in January (46.2 $\mathrm{g}$ in Greensboro and $40.0 \mathrm{~g}$ in Goldsboro), significantly higher than day-neutral cultivars. However, fruit weight of 'Benicia'

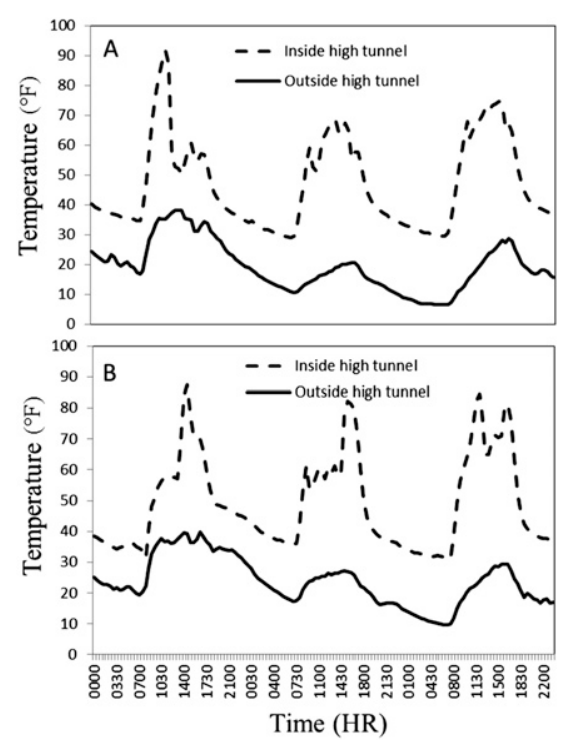

Fig. 1. Air temperatures inside and outside high tunnels from 18 to 20 Feb. 2015: (A) Greensboro, NC, (B) Goldsboro, $\mathrm{NC} ;\left({ }^{\circ} \mathrm{F}-32\right) \div 1.8={ }^{\circ} \mathrm{C}$. 
Table 6. Total soluble solids content of 10 organically managed strawberry cultivars grown under high tunnels in late February, March, April, and May in the 2014-15 season at Greensboro, NC.

\begin{tabular}{lcccccc}
\hline & \multicolumn{7}{c}{ Total soluble solid contents (\%) } \\
\cline { 2 - 7 } Cultivar & $\begin{array}{c}\text { Late } \\
\text { February }\end{array}$ & $\begin{array}{c}\text { Early } \\
\text { March }\end{array}$ & $\begin{array}{c}\text { Late } \\
\text { March }\end{array}$ & $\begin{array}{c}\text { Early } \\
\text { April }\end{array}$ & $\begin{array}{c}\text { Late } \\
\text { April }\end{array}$ & $\begin{array}{c}\text { Early } \\
\text { May }\end{array}$ \\
\hline San Andreas & $9.9 \mathrm{abc}^{\mathrm{z}}$ & 10.3 & $8.2 \mathrm{a}$ & $5.5 \mathrm{abc}$ & $7.0 \mathrm{ab}$ & $9.6 \mathrm{ab}$ \\
Albion & $8.9 \mathrm{bc}$ & 9.9 & $7.5 \mathrm{ab}$ & $6.4 \mathrm{ab}$ & $7.2 \mathrm{ab}$ & $11.3 \mathrm{a}$ \\
Florida Radiance & $11.5 \mathrm{ab}$ & 10.3 & $6.9 \mathrm{abc}$ & $6.1 \mathrm{abc}$ & $7.0 \mathrm{ab}$ & $9.0 \mathrm{ab}$ \\
Benicia & $9.8 \mathrm{abc}$ & 10.8 & $5.2 \mathrm{c}$ & $4.0 \mathrm{c}$ & $5.0 \mathrm{~b}$ & $\mathrm{NA}^{\mathrm{y}}$ \\
Camarosa & $8.4 \mathrm{c}$ & 8.2 & $7.0 \mathrm{abc}$ & $6.2 \mathrm{ab}$ & $8.7 \mathrm{a}$ & $10.8 \mathrm{ab}$ \\
Camino Real & $10.1 \mathrm{abc}$ & 8.9 & $5.2 \mathrm{c}$ & $4.4 \mathrm{bc}$ & $5.1 \mathrm{~b}$ & $8.0 \mathrm{~b}$ \\
Chandler & $10.0 \mathrm{abc}$ & 9.7 & $5.6 \mathrm{bc}$ & $5.8 \mathrm{abc}$ & $5.8 \mathrm{ab}$ & $10.0 \mathrm{ab}$ \\
Strawberry Festival & $11.4 \mathrm{ab}$ & 10.6 & $7.8 \mathrm{ab}$ & $6.8 \mathrm{a}$ & $6.9 \mathrm{ab}$ & $10.8 \mathrm{ab}$ \\
Sweet Charlie & $8.7 \mathrm{bc}$ & 8.6 & $7.3 \mathrm{ab}$ & $7.0 \mathrm{a}$ & $7.9 \mathrm{ab}$ & $11.4 \mathrm{a}$ \\
Winterstar & $12.1 \mathrm{a}$ & 9.9 & $6.4 \mathrm{abc}$ & $4.9 \mathrm{abc}$ & $7.0 \mathrm{ab}$ & $9.8 \mathrm{ab}$ \\
Significant & $* *$ & $\mathrm{NS}$ & $* *$ & $* *$ & $* *$ & $*$ \\
\hline
\end{tabular}

${ }^{\mathrm{z}}$ Means within a column followed by the same letter were not significantly different by Tukey's honest significant difference test at $P \leq 0.05$.

${ }^{\mathrm{N}}$ Not available.

Ns, ${ }^{*},{ }^{*}, * * *$ Nonsignificant or significant at $P \leq 0.05,0.01$, or 0.001 , respectively.

Table 7 . Average fruit weight of 10 organically managed strawberry cultivars grown under high tunnels from November to May in the 2014-15 season at Greensboro and Goldsboro, NC.

\begin{tabular}{lcccccc}
\hline & \multicolumn{7}{c}{ Avg fruit wt $(\mathbf{g})^{\mathrm{z}}$} \\
\cline { 2 - 7 } Cultivar & $\begin{array}{c}\text { November- } \\
\text { December }\end{array}$ & January & February & March & April & May \\
\hline \multicolumn{7}{c}{ Greensboro, NC } \\
San Andreas & $22.2 \mathrm{~b}^{\mathrm{y}}$ & $20.8 \mathrm{bc}$ & $20.2 \mathrm{a}$ & $18.9 \mathrm{c}$ & $16.7 \mathrm{a}$ & $10.7 \mathrm{ab}$ \\
Albion & $13.5 \mathrm{c}$ & $16.8 \mathrm{c}$ & $20.5 \mathrm{a}$ & $19.3 \mathrm{bc}$ & $15.6 \mathrm{ab}$ & $12.2 \mathrm{a}$ \\
Florida Radiance & $42.3 \mathrm{a}$ & $27.1 \mathrm{bc}$ & $24.2 \mathrm{a}$ & $22.2 \mathrm{bc}$ & $14.2 \mathrm{abc}$ & $12.1 \mathrm{a}$ \\
Benicia & NA & $46.2 \mathrm{a}$ & $30.0 \mathrm{a}$ & $31.4 \mathrm{a}$ & $16.5 \mathrm{ab}$ & $8.6 \mathrm{ab}$ \\
Camarosa & NA & $33.3 \mathrm{abc}$ & $26.3 \mathrm{a}$ & $17.4 \mathrm{~cd}$ & $14.6 \mathrm{abc}$ & $10.8 \mathrm{ab}$ \\
Camino Real & NA & $35.0 \mathrm{ab}$ & $26.4 \mathrm{a}$ & $20.4 \mathrm{bc}$ & $17.2 \mathrm{a}$ & $13.0 \mathrm{a}$ \\
Chandler & NA & $22.0 \mathrm{bc}$ & $19.6 \mathrm{a}$ & $13.0 \mathrm{~d}$ & $10.1 \mathrm{~d}$ & $6.7 \mathrm{~b}$ \\
Strawberry Festival & NA & $36.9 \mathrm{ab}$ & $20.6 \mathrm{a}$ & $17.1 \mathrm{~cd}$ & $12.7 \mathrm{bcd}$ & $8.2 \mathrm{ab}$ \\
Sweet Charlie & NA & $29.1 \mathrm{abc}$ & $21.3 \mathrm{a}$ & $17.0 \mathrm{~cd}$ & $11.3 \mathrm{~cd}$ & $9.0 \mathrm{ab}$ \\
Winterstar & NA & $29.9 \mathrm{abc}$ & $27.6 \mathrm{a}$ & $25.0 \mathrm{~b}$ & $15.7 \mathrm{ab}$ & $11.0 \mathrm{ab}$ \\
Significant & $* * *$ & $* *$ & NS & $* * *$ & $* * *$ & $* *$ \\
San Andreas & & Goldsboro, NC & & & \\
Albion & $24.5 \mathrm{~b}$ & $19.6 \mathrm{bc}$ & 22.7 & $27.5 \mathrm{ab}$ & $18.6 \mathrm{abc}$ & 8.0 \\
Florida Radiance & $18.7 \mathrm{c}$ & $20.8 \mathrm{bc}$ & 21.8 & $27.8 \mathrm{ab}$ & $21.8 \mathrm{a}$ & 11.7 \\
Benicia & $30.0 \mathrm{a}$ & $25.7 \mathrm{abc}$ & 19.9 & $27.1 \mathrm{ab}$ & $17.8 \mathrm{abc}$ & 11.9 \\
Camarosa & NA & $40.0 \mathrm{a}$ & 31.8 & $21.9 \mathrm{ab}$ & $19.0 \mathrm{abc}$ & 9.9 \\
Camino Real & NA & $31.8 \mathrm{ab}$ & 25.7 & $21.3 \mathrm{ab}$ & $18.5 \mathrm{abc}$ & 7.5 \\
Chandler & NA & $13.0 \mathrm{c}$ & 26.8 & $12.6 \mathrm{~b}$ & $20.2 \mathrm{ab}$ & 12.7 \\
Strawberry Festival & NA & $23.8 \mathrm{abc}$ & 20.5 & $15.2 \mathrm{~b}$ & $9.6 \mathrm{~d}$ & 6.1 \\
Sweet Charlie & NA & $27.8 \mathrm{abc}$ & 26.6 & $19.3 \mathrm{ab}$ & $14.1 \mathrm{bcd}$ & 10.4 \\
Winterstar & NA & $28.2 \mathrm{abc}$ & 25.3 & $26.7 \mathrm{ab}$ & $12.7 \mathrm{~cd}$ & 7.7 \\
Significant & NA & $27.6 \mathrm{abc}$ & 27.9 & $35.9 \mathrm{a}$ & $13.3 \mathrm{~cd}$ & 8.0 \\
\hline & $* * *$ & $* *$ & NS & $* *$ & $* * *$ & Ns \\
\hline
\end{tabular}

${ }^{\mathrm{z}} \mathrm{lg}=0.0353 \mathrm{oz}$.

${ }^{\mathrm{y}}$ Means within a column followed by the same letter were not significantly different by Tukey's honest significant difference test at $P \leq 0.05$.

${ }^{\mathrm{x}}$ Not available.

Ns, ${ }^{* *},{ }^{* *}$ Nonsignificant or significant at $P \leq 0.01$ or 0.001 , respectively.

decreased dramatically in later months. In May, the average fruit weights of 'Benicia' were 8.6 and $9.9 \mathrm{~g}$ at Greensboro and Goldsboro, respectively. Throughout the season, 'Chandler' consistently had smaller fruit compared with other cultivars. In the peak season, the average fruit weights of 'Chandler' were 10.1 and $9.6 \mathrm{~g}$ at the
Greensboro and Goldsboro sites, respectively, which are significantly lower than other cultivars except Strawberry Festival and Sweet Charlie. Although 'Chandler' is one of the most commonly grown, open-field cultivars in North Carolina, it may not be the best performing cultivar in high tunnels.

Plant health. At Greensboro, younger leaves of 'Benicia' showed crinkling and stunned growth, accompanied by reddish lesions on leaves, petioles, and calyx during peak production season. The crinkling leaves became necrotic and dead and the whole plant declined in 2 weeks. These symptoms were only present on 'Benicia' at Greensboro, and about $80 \%$ of the plants were infected. Plant samples were analyzed by the North Carolina State University Plant Disease and Insect Clinic (PDIC) in Raleigh and no pathogens were found. Analysis of nutrient concentrations in leaves and petioles of strawberry cultivars indicated that 'Benicia' had the lowest magnesium concentration (data not shown). A magnesium deficiency may be part of the cause for the plants decline.

Two-spotted spider mites and crown and root rot (caused by Phytophthora cactorum) were the primary pest problems that limited plant growth and yield at Goldsboro (data not shown). 'Florida Radiance' is highly susceptible to crown and root rot (Whitaker et al., 2013), which caused stunted plant growth and plant decline. This disease was first identified on 'Florida Radiance' in Goldsboro in late March by PDIC, and then severely affected two of the three 'Florida Radiance' plots, which might partially explain the lower yield of 'Florida Radiance' at the Goldsboro site than that of the Greensboro site. The crown rot symptom was not noticeable on other cultivars at Goldsboro until the end of April, when leaves and petioles of Benicia, Camarosa, and Chandler started to wilt and became necrotic. 'Camino Real' seemed to have the least disease incidence (data not shown). This agrees with the result that Camino Real was the most resistant, whereas 'Camarosa' was the most susceptible cultivar to crown and root rot pathogens (Fang et al., 2012). 
Two-spotted spider mites were found on all evaluated strawberry cultivars at the end of the season at Goldsboro. By evaluating two-spotted spider mite resistance using 85 strawberry cultivars, Shanks and Barritt (1975) found that there was no difference in mite populations on the cultivars although some cultivars showed fewer leaf symptoms. By evaluating development of two-spotted spider mites on leaf disks, Monteiro et al. (2014) noticed mortality of the two-spotted spider mite was higher on 'Camarosa', 'Diamante', and 'Seascape' than on other strawberry cultivars. Due to the highly skewed distribution of the population of two-spotted spider mites in the high tunnels, no significant differences in two-spotted spider mite damage were detected among cultivars in the present study (data not shown).

Interest in off-season and organically produced strawberries is increasing among local producers in North Carolina. In the present study, 'Florida Radiance', 'Benicia', 'Winterstar', and 'Chandler' showed high yield potentials. However, 'Chandler' produced small fruit, which can be a potential problem for fresh markets since it requires extra labor for harvesting small-sized berries. Day-neutral cultivars Albion and San Andreas and June-bearing cultivars Florida Radiance, Winterstar, and Camino Real are promising cultivars to target the early market. 'Benicia' produced large berries in the early season, which could be a highly attractive characteristic for early markets such as Thanksgiving, Christmas, and Valentine's Day.

For future studies, increasing plant density of day-neutral cultivars might be an approach to increase total yield per square foot in high tunnels. Given the frost damage to open blossoms that occurred in the winter season, additional frost protection practices such as low tunnels warrant further investigation in North Carolina. Taking into consideration the variable year-to-year environmental conditions and the properties of high-tunnel and organic production systems, further research spanning multiple years is necessary to provide a thorough evaluation of strawberry cultivars.

\section{Literature cited}

Agüero, J.J., S.M. Salazar, D.S. Kirschbaum, and E.F. Jerez. 2015. Factors affecting fruit quality in strawberries grown in a subtropical environment. Ital. J. Food Sci. 15:223-234.

Ballington, J.R., B. Poling, and K. Olive. 2008. Day-neutral strawberry production for season extension in the midsouth. HortScience 43:1982-1986.

Burfield, T. 2013. Benecia strawberry variety grows in popularity. 28 July 2015 . $<$ http://www.thepacker.com/fruitvegetable-news/shipping-profiles/ Benecia-strawberry-variety-grows-inpopularity-191731861.html>.

Carolina Farm Stewardship Association. 2013. Organic produce marketing survey. 28 July 2015 . <https://www. carolinafarmstewards.org/organicproduce-marketing-survey $/>$.

Chandler, C.K., B.M. Santos, N.A. Peres, C. Jouquand, A. Plotto, and C.A. Sims. 2009. 'Florida Radiance' strawberry. HortScience 44:1769-1770.

Chen, D. 2013. The effect of heat on fruit size of day-neutral strawberries. Masters Thesis, Univ. Guelph, Guelph, ON, Canada.

Clark, J.R. and C.E. Finn. 2010. Register of new fruit and nut cultivars list 45 . HortScience 45:716-756.

Faedi, W., F. Mourgues, and C. Rosati. 2002. Strawberry breeding and varieties: Situation and perspectives. Acta Hort. 567:51-59.

Fang, X., D. Phillips, G. Verheyen, H. Li, K. Sivasithamparam, and M.J. Barbetti. 2012. Yields and resistance of strawberry cultivars to crown and root diseases in the field, and cultivar responses to pathogens under controlled environment conditions. Phytopathol. Mediterr. 51:69-84.

Fernandez, G.E. and J.R. Ballington. 2002. Double cropping of strawberries in an annual system using conditioned plug plants and high tunnels. Acta Hort. 614:547-552.

Fernandez, G.E., L.M. Butler, and F.L. Louws. 2001. Strawberry growth and development in an annual plasticulture system. HortScience 36:1219-1223.

Finn, C.E. and J.R. Clark. 2012. Register of new fruit and nut cultivars list 46 . HortScience 47:536-562.

Gasic, K. and J.E. Preece. 2014. Register of new fruit and nut cultivars list 47. HortScience 49:396-421.

Giampieri, F., S. Tulipani, J.M. AlvarezSuarez, J.L. Quiles, B. Mezzetti, and M. Battino. 2012. The strawberry:
Composition, nutritional quality, and impact on human health. Nutrition 28:9-19.

Hoashi-Erhardt, W., P. Moore, D. Collins, A. Bary, and C. Cogger. 2012. Evaluation of day-neutral cultivars for organic strawberry production in Washington. Acta Hort. 1001:167-174.

Hokanson, S.C. and C.E. Finn. 2000. Strawberry cultivar use in North America. HortTechnology 10:94-106.

Huff, P. 2015. Extending the growing season: High tunnels use and farm to school in the upper midwest. 28 July 2015. <http://www.iatp.org/documents / extending-the-growing-season $>$.

Kadir, S., E. Carey, and S. Ennahli. 2006. Influence of high tunnel and field conditions on strawberry growth and development. HortScience 41:329-335.

Maughan, T.L., K.R. Curtis, B.L. Black, and D.T. Drost. 2015. Economic evaluation of implementing strawberry season extension production technologies in the U.S. Intermountain West. HortScience 50:395-401.

McWhirt, A., G. Fernandez, and M. Schroeder-Moreno. 2015. Sustainable practices for plasticulture strawberry production in the southeast. 28 July 2015. $<$ http://content.ces.ncsu.edu/sustainablepractices-for-plasticulture-strawberryproduction-in-the-southeast $/>$.

Mitcham, E.J. 2014. Strawberry. In: K.C. Gross, C.Y. Wang, and M. Saltveit (eds.). The commercial storage of fruits, vegetables, and florist and nursery stocks. U.S. Dept. Agr. Hdbk. No. 66. 28 July 2015. <http://www.ba.ars.usda.gov/hb66/ strawberry.pdf>.

Monteiro, L.B., T.M.A. Kuhn, A.F. Mogor, and E. Da Silva. 2014. Biology of the two-spotted spider mite on strawberry plants. Neotrop. Entomol. 43:183-188.

Ohlemeier, D. 2011. Radiance ranks among rising strawberry varieties. 28 July 2015. <http://www.thepacker.com/ fruit-vegetable-news/shipping-profiles/ Radiance-ranks-among-rising-strawberryvarieties-136143223.html>

Poling, B. 2011. Increasing high tunnel strawberry productivity in the late fall and early winter with day neutral strawberries and the new Florida short day cv. Radiance. 28 July 2015. <http://smallfruits. org/SRSFCReserchFunding/Researchll/ 2011-07.pdf $>$.

Poling, E.B. 1993. Strawberry plasticulture in North Carolina: II. Preplant, planting, and postplant considerations for growing 'Chandler' strawberry on black plastic mulch. HortTechnology 3:383393. 
Poling, E.B., G. Krewer, and J.P. Smith. 2005. Southeast regional strawberry plasticulture production guide. 28 July 2015 . <http://www.smallfruits. org/SmallFruitsRegGuide/Guides / 2005 culturalguidepartlbsl.pdf $>$.

Pollard, J.E., K.L.B. Gast, and C.M. Chundri. 1989. Overwinter rowcovers increase yield and earliness in strawberry. Acta Hort. 265:229-234.

Portz, D.N., G.R. Nonnecke, and T. Fontinel. 2011. Evaluation of day-neutral strawberry plant spacing to maximize production potential. Iowa State Res. Farm Prog. Rpt. Paper 55. 29 July 2015.<http:// lib.dr.iastate.edu/farms_reports/55>.

Rowley, D., B.L. Black, and D. Drost. 2010a. High tunnel strawberry production. 28 July 2015 . <https:// extension.usu.edu/files/publications/ publication/Horticulture_HighTunnels_ 2010-0lpr.pdf>.

Rowley, D., B.L. Black, D. Drost, and D. Feuz. 2010b. Early-season extension using June-bearing 'Chandler'strawberry in high-elevation high tunnels. HortScience 45:1464-1469.

Ruan, J., Y.R. Yeoung, and K.D. Larson. 2011. Influence of cultivar, planting date, and planting material on yield of dayneutral strawberry cultivars in highland areas of Korea. Hort. Environ. Biotechnol. 52:567-575.

Salamé-Donoso, T.P., B.M. Santos, C.K. Chandler, and S.A. Sargent. 2010. Effect of high tunnels on the growth, yields, and soluble solids of strawberry cultivars in Florida. Int. J. Fruit Sci. 10:249-263.

Shanks, C.H. and B.H. Barritt. 1975. Resistance of strawberries to the twospotted spider mite. J. Econ. Entomol. 68:7-10.

Stewart, P.J. and K.M. Folta. 2010. A review of photoperiodic flowering research in strawberry (Fragaria spp.). Crit. Rev. Plant Sci. 29:1-13.

U.S. Department of Agriculture. 2013. Agricultural statistics for 2013. U.S. Dept. Agr., Washington, DC.
U.S. Department of Agriculture. 2014. Strawberry consumption continues to grow. 28 July 2015. <http://www.ers. usda.gov/data-products/chart-gallery/ detail.aspx? chartId $=50317>$.

Whitaker, V.M., C.K. Chandler, B.M. Santos, and N.A. Peres. 2013. 'Florida Radiance' strawberry. Univ. Florida Inst. Food Agr. Sci. Ext. HS 1151. 28 July 2015. <http://edis.ifas.ufl.edu/ hs400>.

Whitaker, V.M., C.K. Chandler, B.M. Santos, N.A. Peres, M.C. do Nascimento Nunes, A. Plotto, and C.A. Sims. 2012. Winterstar' $^{\mathrm{TM}}$ ('FL 05-107') strawberry. HortScience 47:296-298.

Zhao, X., C.B. Rajashekar, E.E. Carey, and W. Wang. 2006. Does organic production enhance phytochemical content of fruit and vegetables? Current knowledge and prospects for research. HortTechnology 16:449-456. 